\title{
Development and Validation for HPLC Method of Assay of Lvermectin and Clorsulon in Combined Pharmaceutical Dosage Form
}

\author{
Mahmoud Mohamed Ali, Elfatih Elbashir, Mohamed N. Abdalaziz \\ Department of Chemistry, Faculty of Pure and Applied Science, International University of Africa., Khartoum, Sudan \\ Email address: \\ Mohdnasr19@gmail.com (M. N. Abdalaziz) \\ ${ }^{*}$ Corresponding author
}

To cite this article:

Mahmoud Mohamed Ali, Elfatih Elbashir, Mohamed N. Abdalaziz. Development and Validation for HPLC Method of Assay of Lvermectin and Clorsulon in Combined Pharmaceutical Dosage Form. International Journal of Homeopathy \& Natural Medicines.

Vol. 3, No. 6, 2017, pp. 45-55. doi: 10.11648/j.ijhnm.20170306.11

Received: September 15, 2017; Accepted: November 6, 2017; Published: January 16, 2018

\begin{abstract}
Stability indicating-HPLC method has been developed for simultaneous estimation of Ivermectin and Clorsulon in their combined dosage form. For RP-HPLC method, all the standard and sample solutions were prepared in methanol. A RPHPLC method has been developed and subsequently validated for simultaneous estimation of Ivermectin and Clorsulon in their combination product. The proposed RP-HPLC method utilizes a Thermo BDS C-18 $(15 \mathrm{~cm} \mathrm{x} 4.6 \mathrm{~mm}, 5 \mu \mathrm{m})$ column, mobile phase consisting of acetonitrile, methanol and purified water in the proportion of 60: 30:10 (v/v/v), and UV detection at 245 $\mathrm{nm}$. The described method was linear over a range of $10-40 \mu \mathrm{g} / \mathrm{ml}$ with a correlation coefficient $\left(\mathrm{r}^{2}\right)$ of 0.9998 for Ivermectin and a range of $100-400 \mu \mathrm{g} / \mathrm{ml}$ with a correlation coefficient $\left(\mathrm{r}^{2}\right)$ of 0.9998 for Clorsulon. Validations of the proposed method were carried out for its accuracy, precision, linearity and range, specificity, LOD and LOQ according to ICH guidelines. A stability-indicating study was also carried out and indicated that this method can also be used for purity and degradation evaluation of these formulations that occurred due to temperature, humidity and time. the method has been successfully applied for the analysis of drugs in formulation.
\end{abstract}

Keywords: Ivermectin, Clorsulon, RP-HPLC, Limit of Detection, Limit of Quantitation

\section{Introduction}

Ivermectin (IVM) is macrocyclic lactone that has been known as a potent, effective and safe antiparasitic drug for 20 years [1]. It is widely used as an antiparasitic agent in domestic animals and is considered the drug of choice for lymphatic filariasis and river blindness (onchocerciasis) in humans [2]. IVM is a member of the Avermectins; this group includes natural compounds produced by fermentation of the soil-dwelling actinomycete Streptomyces avermitilis. IVM, a semi-synthetic derivative of avermectin $\mathrm{B} 1$, consists of an 80:20 mixtures of the equipotent homologous 22, 23 dehydro B1a and B1b [3].

Clorsulon (CLO) is an antihelminthicum. It is used against the adult forms of parasitic flatworms in cattle, in particular from the liver fluke Fasciola hepatica, and against Fasciola gigantica [4]. Clorsulon is chemically 4-Amino-6(trichlorvinyl) benzen-1, 3-disulfonamide [5].
Literature survey reveals a few spectrophotometric and chromatographic methods for the estimation of both drugs as a single component and in combination with other drug [6]. However, no method has been reported for analysis of these drugs in combined dosage form. there is official method for simultaneous estimation of the two drugs in their combined form stated in, United states [7], British [8] or European Pharmacopeias [9].

Ivermectin is a semisynthetic, anthelmintic agent for oral administration. Ivermectin is derived from the avermectins, a class highly active broad-spectrum, anti-parasitic agents isolated from the fermentation products of Streptomyces avermitilis. Ivermectin is a mixture containing at least $90 \% 5$ O-demethyl-22,23-dihydroavermectin A1a and less than 10\% 5-O-demethyl-25-de (1-methylpropyl)-22,23-dihydro-25-(1methylethyl) avermectin A1a, generally referred to as 22,23dihydroavermectin $\mathrm{B} 1 \mathrm{a}$ band $\mathrm{B} 1 \mathrm{~b}$, or $\mathrm{H} 2 \mathrm{~B} 1 \mathrm{a}$ and $\mathrm{H} 2 \mathrm{~B} 1 \mathrm{~b}$, 
respectively. The respective empirical formulas are $\mathrm{C}_{48} \mathrm{H}_{74} \mathrm{O}_{14}$ and $\mathrm{C}_{47} \mathrm{H}_{72} \mathrm{O}_{14}$, with molecular weights of 875.10 and 861.07, respectively. The structural formulas are: component $\mathrm{B} 1 \mathrm{a}, \mathrm{R} \equiv$ $\mathrm{C}_{2} \mathrm{H}_{5}$ component $\mathrm{B} 1 \mathrm{~b}, \mathrm{R} \equiv \mathrm{CH}_{3}$ (see figure 1).

Ivermectin is a white to yellowish-white, nonhygroscopic, crystalline powder with a melting point of about $155^{\circ} \mathrm{C}$. It is insoluble in water but is freely soluble in methanol and soluble in $95 \%$ ethanol [10].

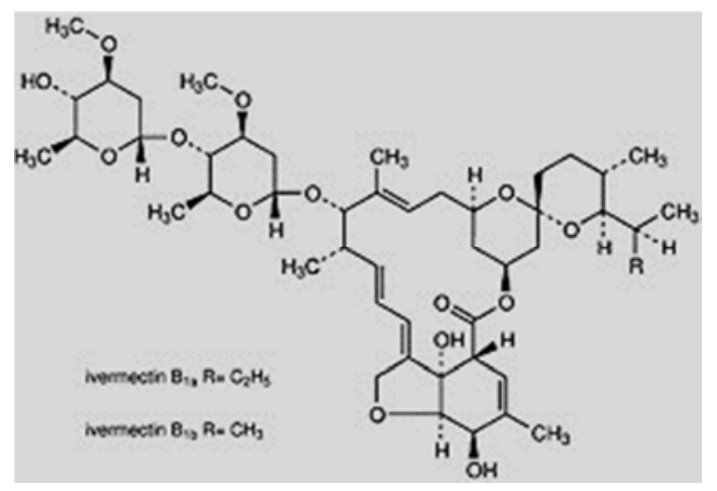

Figure 1. Below is Ivermectin structural formula.

On livestock ivermectin is effective against the major parasitic roundworms: gastrointestinal (e.g. Haemonchus spp, Cooperia spp, Ostertagia spp and Trichostrongylus spp) and pulmonary (e.g. Dictyocaulus spp). It is also effecive against most mites and lice species, and against numerous myiases (e.g. those caused by screwworm flies, bot flies and warble flies) usually regardless of the delivery form (pour-on, injectable, drench or feed additive).

Clorsulon is a substance belonging to the benzenensulphonamide family which is used for the treatment and control of adult flukes. Veterinary medicinal products containing clorsulon are currently marketed in the EU for the treatment of cattle. They are available as injectable formulations to be administered subcutaneously (recommended dose $2 \mathrm{mg} / \mathrm{kg}$ ) or by the oral route (recommended dose $7 \mathrm{mg} / \mathrm{kg}$ ). Clorsulon is frequently used in association with Ivermectin [11].

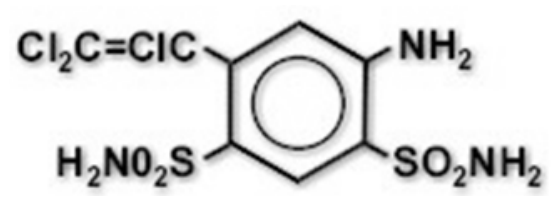

Figure 2. Below is Clorsulon structural formula.

Clorsulon is frequently used in association with Ivermectin. Clorsulon was previously assessed by the CVMP and a toxicological ADI of $0.002 \mathrm{mg} / \mathrm{kg}$ body weight, i.e. $0.120 \mathrm{mg} /$ person was established.

In susceptible flukes, Clorsulon inhibits the glycolytic enzymes 3-phosphoglycerate kinase and phosphoglyceromutase, thereby blocking the EmdenMyerhof glycolytic pathway. The fluke is deprived of its main metabolic energy source and dies.

Clorsulon is approved for use in the treatment of immature and adult forms of Fasciola hepatica (Liver fluke) in cattle. It is not effective against immature flukes less than 8 weeks old. It also has activity against Fasciola gigantica. Although not approved, the drug has been used in practice in various other species (e.g., sheep, llamas). It has activity against F. magna in sheep, but is not completely effective in eradicating the organism after a single dose, thereby severely limiting its clinical usefulness against this parasite. Clorsulon is also not effective against the rumen fluke (Paramphistomum). Therefore, the objective of present communication is to develop simple, rapid and precise spectrophotometric method for the estimation of Ivermectin and clorsulon in combined pharmaceutical dosage form.

\section{Expermental}

Instruments and reagents

HPLC Model (Shimadzu, Kyto. JAPAN), Auto sampler (SIL-20AC), UV/VIS Detector (YL9120), SPD-20AV, prominence Liquid Chromatography model LC-20AB, prominence column Oven model CTO-20A, Degassing Unit model DGU-20A3R \& L C solution software is used for Data acquisition and analysis.

Ivermectin Working Standard (96.2\% purity) was obtained from Aurum Research Centre (Amman, Jordan), Clorsulon Working Standard (100\% purity) was obtained from India Pharma, Acetonitrile (HPLC Grade) \& Methanol (HPLC Grade) were used is obtained from CARLO ERBA Reagents (Italy). The $0.45 \mu \mathrm{m}$ nylon filters were purchased from VIVID Separation\& Filtration (Amman, Jordan), Ivermectin plus Injection (Ivermectin \& Clorsulon) Samples Batch No (T-05) used in Validation are granted by Bash Pharma Pharmaceutical and all other facilities.

Liquid Chromatographic Conditions

Chromatographic conditions were obtained using a stainless steel column (Thermo BDS C-18,150mm x 4.6mm $5.0 \mathrm{~m} \mu$ ), which was maintained at ambient temperature. The analytical wavelength was set at $245 \mathrm{~nm}$ and samples of 10 . $\mu \mathrm{l}$ were injected to HPLC system. The mobile phase consisting of a mixture of Acetonitrile: Methanol: Purified Water in the ratio $(60: 30: 10)$, at a flow rate of $1 \mathrm{ml} / \mathrm{min}$. The mobile phase was filtered through $0.45 \mathrm{~m} \mu$ filter and degassed for 10 minutes by sonication.

Standard Solutions

Standard Stock Solutions

An accurately weighed quantity of $20 \mathrm{mg}$ of Ivermectin and $200 \mathrm{mg}$ of Clorsulon were transferred into a $100 \mathrm{ml}$ volumetric flask. Methanol was added to mark to produce a solution having a concentration of $200 \mu \mathrm{g} / \mathrm{ml}$ of Ivermectin and $2000 \mu \mathrm{g} / \mathrm{ml}$ of Clorsulon.

Preparation of Working Standard

From the standard stock solution $5 \mathrm{ml}$ is pipette out into 50 $\mathrm{ml}$ volumetric flask and made up the volume with methanol to produce a solution having a concentration of $20 \mu \mathrm{g} / \mathrm{ml}$ of Ivermectin and $200 \mu \mathrm{g} / \mathrm{ml}$ of Clorsulon.

Preparation of Assay Working Solution

$2 \mathrm{ml}$ of Ivermectin plus (clorsulon $100 \mathrm{mg}+$ Ivermectin 10 
$\mathrm{mg}$ ) equivalent to $200 \mathrm{mg}$ and $20 \mathrm{mg}$ of Clorsulon and Ivermectin respectively is transferred into a $100 \mathrm{ml}$ volumetric flask. Methanol is added to the mark and ultrasonicated for 5 minutes to produce a solution having a concentration of 200 $\mu \mathrm{g} / \mathrm{ml}$ of Ivermectin and $2000 \mu \mathrm{g} / \mathrm{ml}$ of Clorsulon.

$5 \mathrm{ml}$ of this solution is diluted to $50 \mathrm{ml}$ with the same solvent to produce a Solution having the concentration of 20 $\mu \mathrm{g} / \mathrm{ml}$ of Ivermectin and $200 \mu \mathrm{g} / \mathrm{ml}$ of Clorsulon.

Method Validation

Method validation is the process of proving that an analytical method is acceptable for its intended purpose [12]. For pharmaceutical methods, guidelines from the United States Pharmacopeia (USP), International Conference on Harmonization ( $\mathrm{ICH}$ ), and the Food and Drug Administration (FDA) provide a framework for performing such validations. In general, methods for regulatory submission must include studies on specificity, linearity, accuracy, precision, range, detection limit, quantitation limit, and robustness [13].

Procedure

System Suitability Test

From the standard working solution, the concentration was prepared having $20 \mu \mathrm{g} / \mathrm{ml}$ of Ivermectin and $200 \mu \mathrm{g} / \mathrm{ml}$ of Clorsulon. The system suitability test was performed from Five replicate injections of standard working solution.

Linearity

In order to study linearity of the response, a series of Seven concentrating levels from $50 \%$ - $200 \%$ of assay analytes concentrations were prepared from stock solutions. The linearity performed was used for the determination of limits of quantification and detection.

From standard stock solution having the concentration 200 $\mu \mathrm{g} / \mathrm{ml}$ of Ivermectin and $2000 \mu \mathrm{g} / \mathrm{ml}$ of Clorsulon.

Transfer accurately the specified volume into each of 100$\mathrm{ml}$ volumetric flask to obtain the required working standard concentrations explained as follows:

Clorsulon Linearity

$100 \mu \mathrm{g} / \mathrm{ml}: 5 \mathrm{ml}$ was transferred from $2000 \mu \mathrm{g} / \mathrm{ml}$ standard stock solution to $100-\mathrm{ml}$ volumetric flask, then made up to volume with Methanol (50\%).

$150 \mu \mathrm{g} / \mathrm{ml}: 7.5 \mathrm{ml}$ was transferred from $2000 \mu \mathrm{g} / \mathrm{ml}$ standard stock solution to $100-\mathrm{ml}$ volumetric flask, then made up to volume with Methanol (75\%).

$200 \mu \mathrm{g} / \mathrm{ml}: 10 \mathrm{ml}$ was transferred from $2000 \mu \mathrm{g} / \mathrm{ml}$ standard stock solution to $100-\mathrm{ml}$ volumetric flask, then made up to volume with Methanol (100\%).

$250 \mu \mathrm{g} / \mathrm{ml}: 12.5 \mathrm{ml}$ was transferred from $2000 \mu \mathrm{g} / \mathrm{ml}$ standard stock solution to $100-\mathrm{ml}$ volumetric flask, then made up to volume with Methanol (125\%).

$300 \mu \mathrm{g} / \mathrm{ml}: 15 \mathrm{ml}$ was transferred from $2000 \mu \mathrm{g} / \mathrm{ml}$ standard stock solution to $100-\mathrm{ml}$ volumetric flask, then made up to volume with Methanol (150\%).

$350 \mu \mathrm{g} / \mathrm{ml}: 17.5 \mathrm{ml}$ was transferred from $2000 \mu \mathrm{g} / \mathrm{ml}$ standard stock solution to $100-\mathrm{ml}$ volumetric flask, then made up to volume with Methanol (175\%).

$400 \mu \mathrm{g} / \mathrm{ml}: 20 \mathrm{ml}$ was transferred from $2000 \mu \mathrm{g} / \mathrm{ml}$ standard stock solution to $100-\mathrm{ml}$ volumetric flask, then made up to volume with Methanol (200\%).

\section{Ivermectin Linearity}

$10 \mu \mathrm{g} / \mathrm{ml}: 5 \mathrm{ml}$ was transferred from $200 \mu \mathrm{g} / \mathrm{ml}$ standard stock solution to $100-\mathrm{ml}$ volumetric flask, then made up to volume with Methanol (50\%).

$15 \mu \mathrm{g} / \mathrm{ml}: 7.5 \mathrm{ml}$ was transferred from $200 \mu \mathrm{g} / \mathrm{ml}$ standard stock solution to $100-\mathrm{ml}$ volumetric flask, then made up to volume with Methanol (75\%).

$20 \mu \mathrm{g} / \mathrm{ml}: 10 \mathrm{ml}$ was transferred from $200 \mu \mathrm{g} / \mathrm{ml}$ standard stock solution to $100-\mathrm{ml}$ volumetric flask, then made up to volume with Methanol (100\%).

$25 \mu \mathrm{g} / \mathrm{ml}: 12.5 \mathrm{ml}$ was transferred from $200 \mu \mathrm{g} / \mathrm{ml}$ standard stock solution to $100-\mathrm{ml}$ volumetric flask, then made up to volume with Methanol (125\%).

$30 \mu \mathrm{g} / \mathrm{ml}: 15 \mathrm{ml}$ was transferred from $200 \mu \mathrm{g} / \mathrm{ml}$ standard stock solution to $100-\mathrm{ml}$ volumetric flask, then made up to volume with Methanol (150\%).

$35 \mu \mathrm{g} / \mathrm{ml}: 17.5 \mathrm{ml}$ was transferred from $200 \mu \mathrm{g} / \mathrm{ml}$ standard stock solution to $100-\mathrm{ml}$ volumetric flask, then made up to volume with Methanol (175\%).

$40 \mu \mathrm{g} / \mathrm{ml}: 20 \mathrm{ml}$ was transferred from $200 \mu \mathrm{g} / \mathrm{ml}$ standard stock solution to $100-\mathrm{ml}$ volumetric flask, then made up to volume with Methanol (200\%).

Statistical Analysis and Calculation Formula Used

Linearity data should be evaluated using appropriate statistical methods.

A simple regression line of the detector response versus the sample concentration is the most common means of evaluation. Regulatory agencies require the submission of the correlation coefficient, y-intercept, slope of the regression line, and the residual sum of squares for linearity evaluation.

For the current study statistics data analysis (Stata Software) is used (Texas, USA).

Formula:

$$
\text { Assay } \%=\frac{A t}{A s} \times \frac{C s}{C t} \times 100
$$

Where: At $=$ Area of the Test

As $=$ Area of the Standard

$\mathrm{Cs}=$ Concentration of the Standard

$\mathrm{Ct}=$ Concentration of the Test

Limit of Detection

The LOD is the smallest amount of analyte that can be detected, but not necessarily quantitated using a given method. This parameter is important in the use of limit tests as it sets the level below which the method cannot function.

There are several means of calculating LOD for HPLC methods. The most common approach is to determine the sample amount that provides a signal-to-noise ratio of $3: 1$. Many chromatographic data acquisition systems provide integrated functions to determine the signal-to-noise ratio that are easily employed by analyst.

An alternative to the signal-to-noise approach is to estimate LOD based on the standard deviation of response. For this calculation, $\mathrm{LOD}=3.3(\mathrm{SD} / \mathrm{S})$, where $\mathrm{SD}$ is the standard deviation of the response based on the standard deviation of the blank, the residual standard deviation of the regression line, and the standard deviation of the y-intercepts of the regression 
line, and $\mathrm{S}$ is the slope of the calibration curve.

Root MSE (SD) = the standard deviation of the $y$ intercepts of the regression line

Limit of Quantification

The LOQ is the lowest level that an analyte can be quantitated with any degree of certainty.

The LOQ can be determined by a signal-to-noise ratio of $10: 1$, or approximated by multiplying the LOD by 3.3 . As with LOD, this function is easily obtained from current dataacquisition software. Similarly, LOQ can be estimated by the equation $\mathrm{LOQ}=10(\mathrm{SD} / \mathrm{S})$

Root MSE (SD) = the standard deviation of the $y$ intercepts of the regression

Specificity

Specificity is the ability of a method to discriminate between the analyte (s) of interest and other components that are present in the sample.

Placebo of the Clorsulon and Ivermectin Injection, equivalent to the sample weight was taken and solution prepared similarly to the sample solution. The solution was analyzed as per the proposed method. Sample solution was also analyzed as per the proposed method. No interference from placebo was observed at the retention time of the drugs peaks. The absence of a peak eluting at the retention time of the active ingredient is sufficient to demonstrate specificity for excipients.

Accuracy

Accuracy is the closeness in agreement between the accepted true value or a reference value and the measured result obtained. Accuracy studies are usually evaluated by determining the recovery of a spiked sample of the analyte into the matrix of the sample to be analyzed.

The accuracy of the assay method was evaluated with the recovery of the standards from excipients. Three different quantities (low, medium and high i.e. $80 \%, 100 \%$ and $120 \%$ ) of the authentic standards were added to the placebo. Sample solutions are prepared in triplicate for each spike level as described in the test preparation.

Test Solution

An accurately weighed quantity of $20 \mathrm{mg}$ of Ivermectin and $200 \mathrm{mg}$ of Clorsulon were transferred into each of the three $100 \mathrm{ml}$ volumetric flasks. $2 \mathrm{ml}$ of Ivermectin plus (clorsulon $100+$ Ivermectin $10 \mathrm{mg}$ ) placebo was added to the each. then methanol was added to the mark and the flasks were mixed and sonicated for 5 minutes to produce a solutions having a concentrations of $200 \mu \mathrm{g} / \mathrm{ml}$ of Ivermectin and $2000 \mu \mathrm{g} / \mathrm{ml}$ of Clorsulon.

An accurately 4, 5, and 6 milliliters of each test solutions prepared in (1) in triplicate were Transferred to nine $50 \mathrm{ml}$ volumetric flasks and made up to the volume with methanol to produce a solutions having a concentration levels of $80 \%$ (160 $\mu \mathrm{g} / \mathrm{ml}$ of clorsulon, $16 \mu \mathrm{g} / \mathrm{ml}$ of ivermectin), $100 \%$ (200 $\mu \mathrm{g} / \mathrm{ml}$ of clorsulon, $20 \mu \mathrm{g} / \mathrm{ml}$ of ivermectin) and $120 \%$ (240 $\mu \mathrm{g} / \mathrm{ml}$ of clorsulon, $24 \mu \mathrm{g} / \mathrm{ml}$ of ivermectin) respectively.

Shake well and Filter through $0.45 \mu$ nylon filter and inject into the HPLC system.

Standard Solution

An accurately weighed quantity of $20 \mathrm{mg}$ of Ivermectin and $200 \mathrm{mg}$ of Clorsulon were transferred to a $100 \mathrm{ml}$ volumetric flask. then methanol was to the mark and ultrasonicated for 5 minutes to produce a solution having a concentration of $200 \mu \mathrm{g} / \mathrm{ml}$ of Ivermectin and $2000 \mu \mathrm{g} / \mathrm{ml}$ of Clorsulon. $5 \mathrm{ml}$ of this solution was diluted to $50 \mathrm{ml}$ with methanol to produce a solution having the concentration of $20 \mu \mathrm{g} / \mathrm{ml}$ of Ivermectin and $200 \mu \mathrm{g} / \mathrm{ml}$ of Clorsulon.

Precision

Precision is a measure of the ability of the method to generate reproducible results. For the precision study, precision of the assay was determined by repeatability (intraday) and intermediate precision (inter-day) in triplicate. Repeatability refers to the use of the analytical procedure over a short period of time that was evaluated by assaying of six determinations at $100 \%$ of the test concentrations during the same day prepared in the manner described above in the Assay working Solution Page No (11). Intermediate precision was assessed by comparing the assay of six determinations at $100 \%$ of the test concentrations on different days (3 days) prepared in the same manner for repeatability.

Robustness

Robustness is a measure of the performance of a method when small, deliberate changes are made to the method conditions. The intent of this validation parameter is to identify which, if any, of the method conditions are the most critical to the successful performance of the method.

The Robustness was determined by injecting triplicate injections of standard and by assaying of six determinations at $100 \%$ of the test concentrations of the same Ivermectin plus Batch used in the precision Study.

Robustness of the method was checked by varying the instrumental conditions such as flow rate, Organic content in mobile phase ratio, wavelength of detection.

\section{Results and Discussion}

System Suitability

Table 1. Result of System suitability test.

\begin{tabular}{|c|c|c|c|c|}
\hline Injection \# & Ret. Time & Peak Area & Theo. Plate & Tailing Factor \\
\hline 1 & 1.726 & 1891931 & 1752.694 & 1.577 \\
\hline 2 & 1.726 & 1892528 & 1770.867 & 1.599 \\
\hline 3 & 1.726 & 1890773 & 1785.780 & 1.603 \\
\hline 4 & 1.726 & 1890626 & 1814.087 & 1.609 \\
\hline 5 & 1.726 & 1889911 & 1850.867 & 1.604 \\
\hline Average & 1.726 & 1891153.8 & 1794.859 & 1.5984 \\
\hline STDEV & 0 & 1056.0065 & 38.54395 & 0.012482 \\
\hline RSD & 0 & 0.06 & 2.15 & 0.78 \\
\hline
\end{tabular}


Table 2. Result of System suitability test.

\begin{tabular}{llllll}
\hline Injection No. & Ret. Time & Peak Area & Theo. Plate & Tailing Factor & Resolution \\
\hline 1 & 6.612 & 394981 & 5309.001 & 0.977 & 18.510 \\
2 & 6.598 & 394743 & 5390.561 & 0.978 & 18.612 \\
3 & 6.586 & 394593 & 5493.684 & 0.978 & 18.735 \\
4 & 6.572 & 394663 & 5621.079 & 0.979 & 18.900 \\
5 & 6.557 & 393981 & 5724.026 & 0.980 & 19.051 \\
Average & 6.57825 & 394592.2 & 5557.338 & 0.97875 & 18.8245 \\
STDEV & 0.021517 & 168.8471 & 168.1153 & 0.00114 & 0.217541 \\
RSD & 0.33 & 0.04 & 3.03 & 0.12 & 1.15 \\
\hline
\end{tabular}

Clorsulon Linearity

Table 3. Data for Calibration Curve for Clorsulon.

\begin{tabular}{lll}
\hline Percent Level & Concentration $(\mathbf{X})$ & Peak Area Response (Y) \\
\hline $50 \%$ & $100 \mu \mathrm{g} / \mathrm{ml}$ & 918728.3 \\
$75 \%$ & $150 \mu \mathrm{g} / \mathrm{ml}$ & 136114 \\
$100 \%$ & $200 \mu \mathrm{g} / \mathrm{ml}$ & 1837846 \\
$125 \%$ & $250 \mu \mathrm{g} / \mathrm{ml}$ & 2313903 \\
$150 \%$ & $300 \mu \mathrm{g} / \mathrm{ml}$ & 2731636 \\
$175 \%$ & $350 \mu \mathrm{g} / \mathrm{ml}$ & 3236974 \\
$200 \%$ & $400 \mu \mathrm{g} / \mathrm{ml}$ & 3667866 \\
\hline
\end{tabular}

$\mathrm{X}=$ Concentration of Clorsulon Standard in $\mu \mathrm{g} / \mathrm{ml}$. $\mathrm{y}=$ Peak Area Response.

Clorsulon Concentration in $\mu \mathrm{g} / \mathrm{ml}$ Vis Fitted Peak response Graph

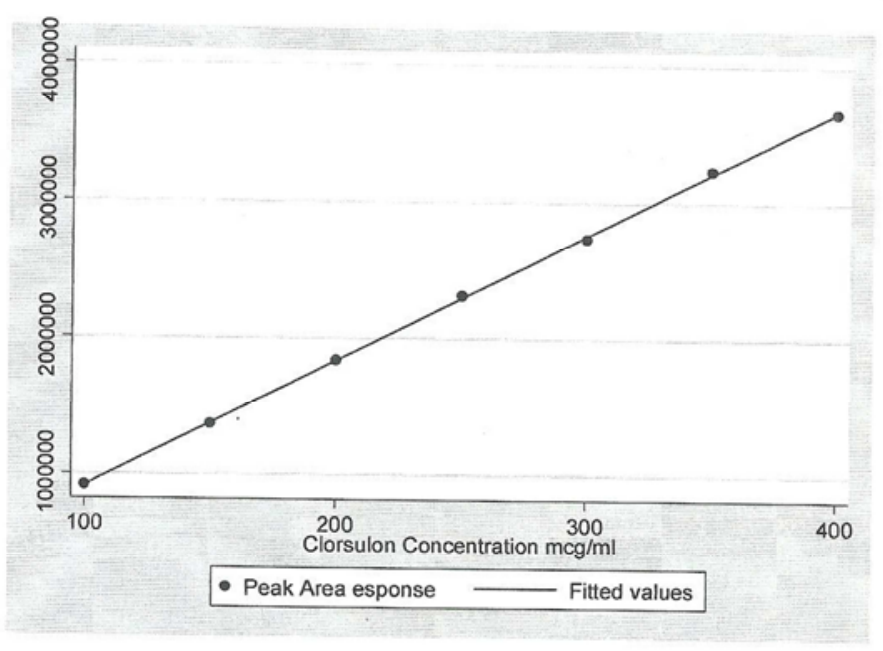

Slope (b): 9197.802

y- Intercept (a): - 2869.502

Regression Equation(y): - 2869.502 + 9197.802

Figure 3 Calibration Curve of Clorsulon.

Table 4 Data summarize of regression of y and x parameters for Clorsulon.

\begin{tabular}{llll}
\hline No. & Parameter & Symbol & Value \\
\hline 1 & R- Squared & $\mathrm{r}^{2}$ & 0.9998 \\
2 & Slope coefficient (x) & $\mathrm{A}$ & -2869.502 \\
3 & Intercept (constant) coefficient & $\mathrm{B}$ & 9197.802 \\
4 & Regression equation & $\mathrm{Y}=\mathrm{a} * \mathrm{C}+\mathrm{b}$ & $\mathrm{Y}=-2869.502+9197.802$ \\
\hline
\end{tabular}

Ivermectin Linearity 
Table 5. Data for Calibration Curve for Ivermectin.

\begin{tabular}{lll}
\hline Percent Level & Concentration $(\mathbf{X})$ & Peak Area Response (Y) \\
\hline $50 \%$ & $10 \mu \mathrm{g} / \mathrm{ml}$ & 191366.7 \\
$75 \%$ & $15 \mu \mathrm{g} / \mathrm{ml}$ & 286604 \\
$100 \%$ & $20 \mu \mathrm{g} / \mathrm{ml}$ & 385881 \\
$125 \%$ & $25 \mu \mathrm{g} / \mathrm{ml}$ & 487493.7 \\
$150 \%$ & $30 \mu \mathrm{g} / \mathrm{ml}$ & 576688 \\
$175 \%$ & $35 \mu \mathrm{g} / \mathrm{ml}$ & 684579.7 \\
$200 \%$ & $40 \mu \mathrm{g} / \mathrm{ml}$ & 777129.7 \\
\hline
\end{tabular}

$\mathrm{X}=$ Concentration of Clorsulon Standard in $\mu \mathrm{g} / \mathrm{ml}$.

$\mathrm{y}=$ Peak Area Response.

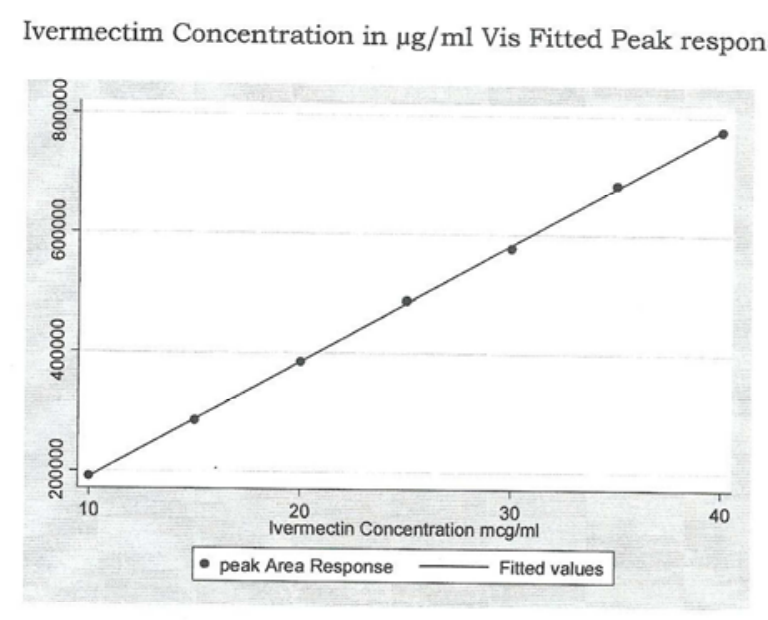

Slope (b): 19600.34

y - Intercept (a): - 5759.511

Regression Equation(y): $\quad-\mathbf{5 7 5 9 . 5 1 1}+\mathbf{1 9 6 0 0 . 3 4}$

Figure 4. Calibration Curve of Fitted Values of Ivermectin peak Areas.

Table 6. Data summarize of regression of y and x parameters for Ivermectin.

\begin{tabular}{llll}
\hline No. & Parameter & Symbol & Value \\
1 & R- Squared & $\mathrm{r}^{2}$ & 0.9998 \\
2 & Slope coefficient $(\mathrm{x})$ & $\mathrm{A}$ & 19600.34 \\
3 & Intercept (constant) coefficient & $\mathrm{B}$ & -5759.511 \\
4 & Regression equation & $\mathrm{Y}=\mathrm{a} * \mathrm{C}+\mathrm{b}$ & $\mathrm{Y}=19600.34-5759.511$ \\
& & $\mathrm{Y}=-5759.511+19600.34 * \mathrm{C}$ \\
\hline
\end{tabular}

Limit of Detection Calculations

Ivermectin Component

The method based on the residual standard deviation of a regression line and slope.

The limit of detection and the limit of quantification of the drug were calculated using the following equations as per ICH guidelines.

$$
\mathrm{LOD}=3.3(\mathrm{SD} / \mathrm{S}) \text {. }
$$

$(\mathrm{SD})=$ the standard deviation of the response $=$ Root MSE $=3620.8$

$(\mathrm{S})=$ the slope of the calibration curve $=19600.34$

$\mathrm{LOQ}=10(\mathrm{SD} / \mathrm{S})$.

The standard deviation of the response can be determined based on the standard deviation of y-intercepts of regression lines.

Root MSE is the standard deviation of the error term, and is the square root of the Mean Square Residual (or Error) =
$\mathrm{SD}=3620.8$

The limit of detection (LOD) and the limit of quantification (LOQ)of the drug were established by evaluating the minimum level at which the analyte could be readily detected and quantified.

$\mathrm{LOD}=3.3 \times(3620.8 / 19600.34)=0.61 \mu \mathrm{g} / \mathrm{ml}$

$\mathrm{LOQ}=10 \times(3620.8 / 19600.34)=1.80 \mu \mathrm{g} / \mathrm{ml}$

Clorsulon Component

The method based on the residual standard deviation of a regression line and slope.

The limit of detection and the limit of quantification of the drug were calculated using the following equations as per ICH guidelines.

$\mathrm{LOD}=3.3(\mathrm{SD} / \mathrm{S})$.

$(\mathrm{SD})=$ the standard deviation of the response $=$ Root MSE $=17180$

$(S)=$ the slope of the calibration curve $=9197.802$ 
$\mathrm{LOQ}=10(\mathrm{SD} / \mathrm{S})$

The standard deviation of the response can be determined based on the standard deviation of y-intercepts of regression lines.

Root MSE is the standard deviation of the error term, and is the square root of the Mean Square Residual (or Error) = $\mathrm{SD}=17180$
The limit of detection (LOD) and the limit of quantification (LOQ) of the drug were established by evaluating the minimum level at which the analyte could be readily detected and quantified.

$\mathrm{LOD}=3.3 \times(17180 / 9197.802)=6.16 \mu \mathrm{g} / \mathrm{ml}$ $\mathrm{LOQ}=10 \times(17180 / 9197.802)=18.68 \mu \mathrm{g} / \mathrm{ml}$ Specificity

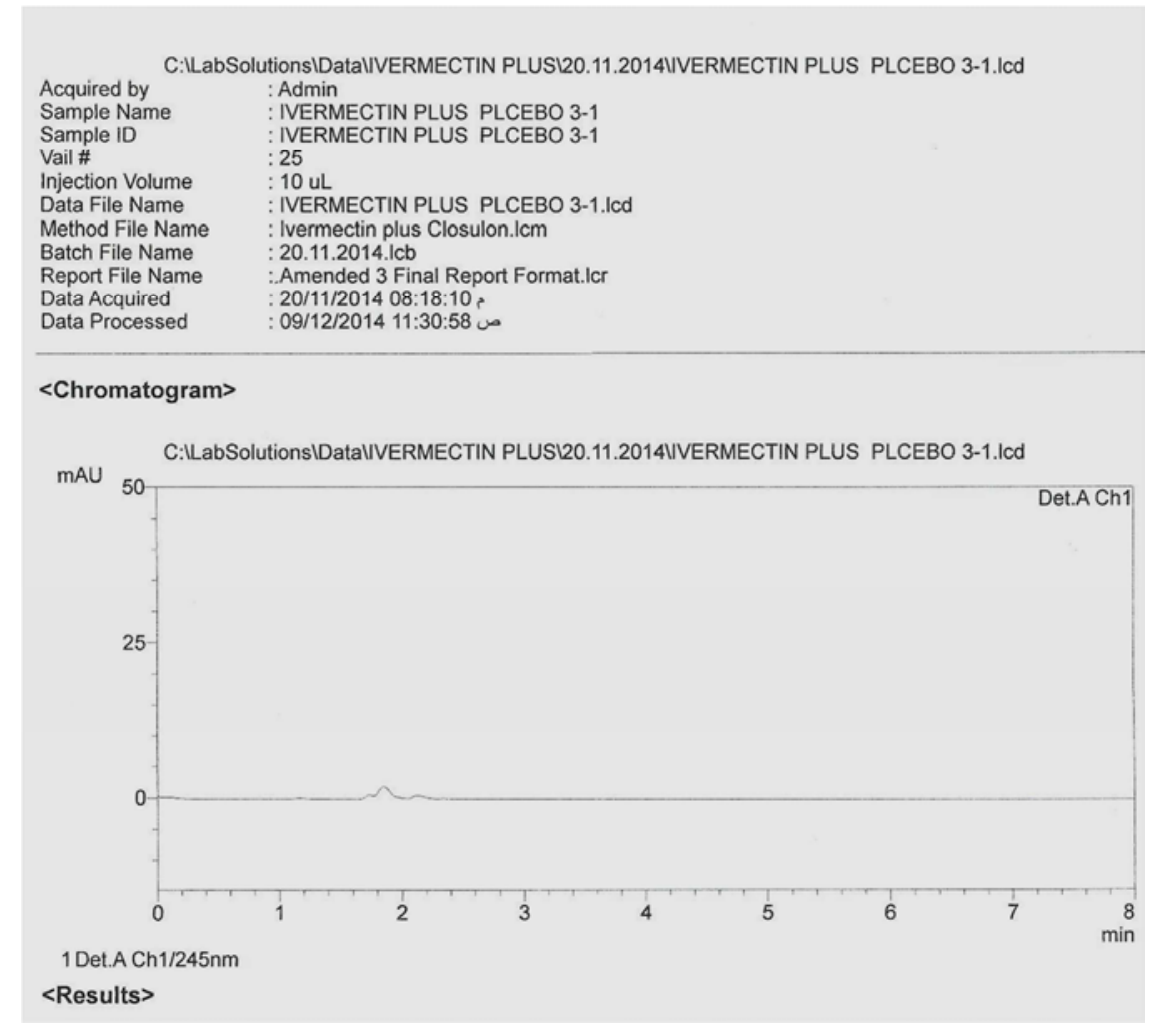

Figure 5. Above shows Placebo chromatogram.

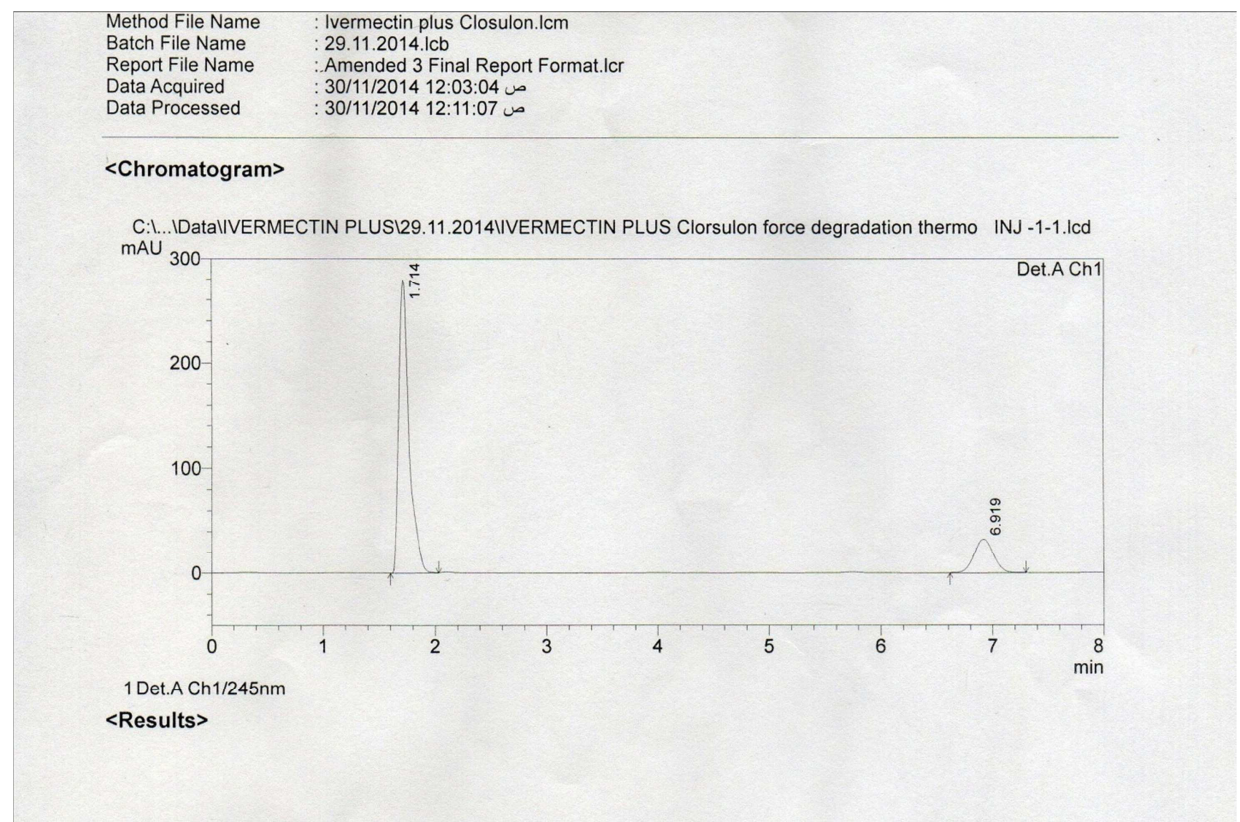

Figure 6. Above shows the combined drug Sample (Ivermectin + Clorsulon) chromatogram. 
Accuracy

Table 7. Results of recovery of Clorsulon from spiked placebo.

\begin{tabular}{lllll}
\hline Spike level (\%) & Average ' $\boldsymbol{\mu g} / \mathbf{m l}$ ' added & Average ' $\boldsymbol{\mu g} / \mathbf{m l}$ ' found & Mean\% recovery & RSD (\%) \\
\hline $80 \%$ & $160 \mu \mathrm{g} / \mathrm{ml}$ & $159.98 \mu \mathrm{g} / \mathrm{ml}$ & 99.98 & 1.19 \\
$100 \%$ & $200 \mu \mathrm{g} / \mathrm{ml}$ & $199.7 \mu \mathrm{g} / \mathrm{ml}$ & 99.85 & 0.65 \\
$120 \%$ & $240 \mu \mathrm{g} / \mathrm{ml}$ & $239.83 \mu \mathrm{g} / \mathrm{ml}$ & 99.93 & 0.59 \\
Average Recovery\%=99.92\% & & & \\
Mean RSD\%=0.06\% & & & \\
\hline
\end{tabular}

*Acceptance Criteria: Recovery\% is $98-102 \%$.

Table 8. Results of recovery of Ivermectin from spiked placebo.

\begin{tabular}{lllll}
\hline Spike level (\%) & Average ' $\boldsymbol{\mu g} / \mathbf{m l}$ ' added & Average ' $\boldsymbol{\mu g} / \mathbf{m l}$ ' found & Mean\% recovery & RSD (\%) \\
\hline $80 \%$ & $16 \mu \mathrm{g} / \mathrm{ml}$ & $15.86 \mu \mathrm{g} / \mathrm{ml}$ & 99.14 & 0.94 \\
$100 \%$ & $20 \mu \mathrm{g} / \mathrm{ml}$ & $19.9 \mu \mathrm{g} / \mathrm{ml}$ & 99.52 & 0.43 \\
$120 \%$ & $24 \mu \mathrm{g} / \mathrm{ml}$ & $23.91 \mu \mathrm{g} / \mathrm{ml}$ & 99.64 & 0.70 \\
Average Recovery\%=99.43\% & & & \\
Mean RSD\%=0.26\% & & & \\
\hline
\end{tabular}

*Acceptance Criteria: Recovery\% is $98-102 \%$.

Table 9. Results of the intra-day precision test (repeatability).

\begin{tabular}{ll}
\hline No. & Clorsulon Assay Results \\
\hline Assay-1 & $98.57 \%$ \\
Assay-2 & $97.75 \%$ \\
Assay-3 & $97.49 \%$ \\
Assay-4 & $98.10 \%$ \\
Assay-5 & $97.13 \%$ \\
Assay-6 & $97.54 \%$ \\
Assay-7 & $97.28 \%$ \\
Assay-8 & $97.23 \%$ \\
Average & $97.50 \%$ \\
STDEV & 0.33 \\
RSD\% & 0.34 \\
\hline
\end{tabular}

*Acceptance Criteria: RSD $\leq 2$.

Table 10. Results of the intra-day precision test (repeatability).

\begin{tabular}{ll}
\hline No. & Ivermectin Assay Results \\
\hline Assay-1 & $98.64 \%$ \\
Assay-2 & $97.62 \%$ \\
Assay-3 & $97.34 \%$ \\
Assay-4 & $97.94 \%$ \\
Assay-5 & $96.89 \%$ \\
Assay-6 & $97.44 \%$ \\
Assay-7 & $97.08 \%$ \\
Assay-8 & $96.96 \%$ \\
Average & $97.48 \%$ \\
STDEV & 0.58 \\
RSD\% & 0.59 \\
\hline
\end{tabular}

*Acceptance Criteria: RSD $\leq 2$.

Intermediate Precision

Table 11. Results of the inter-day precision test (intermediate precision).

\begin{tabular}{llll}
\hline \multirow{2}{*}{ Replicates } & \multicolumn{3}{l}{ Clorsulon Assay Results } \\
\cline { 2 - 4 } & Day-1 & Day-2 & Day-3 \\
\hline Assay-1 & $100.22 \%$ & $98.63 \%$ & $99.93 \%$ \\
Assay-2 & $100.22 \%$ & $98.18 \%$ & $97.98 \%$ \\
Assay-3 & $100.94 \%$ & $99.02 \%$ & $98.07 \%$ \\
Assay-4 & $98.66 \%$ & $98.56 \%$ & $98.37 \%$ \\
Assay-5 & $98.02 \%$ & $99.02 \%$ & $98.09 \%$ \\
Assay-6 & $100.16 \%$ & $98.96 \%$ & $97.35 \%$ \\
\hline
\end{tabular}

\begin{tabular}{llll}
\hline \multirow{2}{*}{ Replicates } & \multicolumn{3}{l}{ Clorsulon Assay Results } \\
\cline { 2 - 4 } & Day-1 & Day-2 & Day-3 \\
\hline Average & $99.7 \%$ & $98.7 \%$ & $98.5 \%$ \\
STDEV & 1.11 & 0.33 & 0.86 \\
RSD $\%$ & 1.11 & 0.33 & 0.88 \\
\hline
\end{tabular}

Table 12. Results of Overall inter-day precision test (intermediate precision).

\begin{tabular}{ll}
\hline Assay & \% Content \\
\hline Day-1 & 99.7 \\
Day-2 & 98.7 \\
Day-3 & 98.5 \\
Average & 98.9 \\
STDEV & 0.64 \\
RSD\% & 0.65 \\
\hline
\end{tabular}

*Acceptance Criteria: RSD $\leq 2$.

Intermediate Precision

Table 13. Results of the inter-day precision test (intermediate precision).

\begin{tabular}{llll}
\hline \multirow{2}{*}{ Replicates } & \multicolumn{3}{l}{ Ivermectin Assay Results } \\
\cline { 2 - 4 } & Day-1 & Day-2 & Day-3 \\
\hline Assay-1 & $97.8 \%$ & $99.3 \%$ & $99.0 \%$ \\
Assay-2 & $97.5 \%$ & $99.3 \%$ & $95.9 \%$ \\
Assay-3 & $97.9 \%$ & $100 \%$ & $96.6 \%$ \\
Assay-4 & $97.3 \%$ & $98.1 \%$ & $97.3 \%$ \\
Assay-5 & $98.3 \%$ & $97.1 \%$ & $96.6 \%$ \\
Assay-6 & $97.5 \%$ & $99.6 \%$ & $95.7 \%$ \\
Average & $97.7 \%$ & $98.9 \%$ & $96.9 \%$ \\
STDEV & 0.36 & 1.08 & 1.19 \\
RSD\% & 0.37 & 1.09 & 1.23 \\
\hline
\end{tabular}

Table 14. Results of Overall inter-day precision test (intermediate precision).

\begin{tabular}{ll}
\hline Assay & \% Content \\
\hline Day-1 & 97.7 \\
Day-2 & 98.9 \\
Day-3 & 96.9 \\
Average & 97.8 \\
STDEV & 1.0 \\
RSD\% & 1.0 \\
\hline
\end{tabular}

*Acceptance Criteria: RSD $\leq 2$. 
Robustness

Table 15. Summary of Robustness Parameters.

\begin{tabular}{|c|c|c|c|c|}
\hline \multirow{2}{*}{ Parameter Changed } & \multirow{2}{*}{ Clorsulon } & \multirow{2}{*}{ Ivermectin } & \multicolumn{2}{|c|}{ Present method } \\
\hline & & & Clorsulon & Ivermectin \\
\hline \multirow{5}{*}{ Wavelength $246 \mathrm{~nm}$} & 98.6 & 98.3 & 98.5 & 98.6 \\
\hline & 97.8 & 97.3 & 97.7 & 97.6 \\
\hline & 98.2 & 97.6 & 98.1 & 97.9 \\
\hline & 97.4 & 97.1 & 97.5 & 97.4 \\
\hline & 97.6 & 96.8 & 97.2 & 97.0 \\
\hline STDEV & 0.46 & 0.54 & 0.48 & 0.56 \\
\hline RSD $\%$ & 0.47 & 0.55 & 0.49 & 0.57 \\
\hline
\end{tabular}

(Overall RSD) $* * *$ Acceptance Criteria: $\mathrm{RSD} \leq 2 \%$.

Table 16. Summary of Robustness Parameters.

\begin{tabular}{|c|c|c|c|c|}
\hline \multirow{2}{*}{ Parameter changed } & \multirow{2}{*}{ Clorsulon } & \multirow{2}{*}{ Ivermectin } & \multicolumn{2}{|c|}{ Present Method as Standard } \\
\hline & & & Clorsulon & Ivermectin \\
\hline \multirow{5}{*}{ Flow rate $0.8 \mathrm{ml} / \mathrm{min}$} & 97.6 & 97.1 & 98.5 & 98.6 \\
\hline & 97.4 & 96.7 & 97.7 & 97.6 \\
\hline & 97.9 & 97.3 & 97.4 & 97.3 \\
\hline & 97.2 & 96.9 & 98.1 & 97.9 \\
\hline & 97.3 & 96.8 & 97.5 & 97.4 \\
\hline Average & 97.4 & 96.9 & 97.7 & 97.6 \\
\hline STDEV & 0.29 & 0.28 & 0.48 & 0.56 \\
\hline RSD $\%$ & 0.30 & 0.29 & 0.49 & 0.57 \\
\hline
\end{tabular}

(Overall RSD) $* * *$ Acceptance Criteria: $\mathrm{RSD} \leq 2 \%$.

Table 17. Summary of Robustness Parameters.

\begin{tabular}{|c|c|c|c|c|}
\hline \multirow{2}{*}{ Parameter changed } & \multirow{2}{*}{ Clorsulon } & \multirow{2}{*}{ Ivermectin } & \multicolumn{2}{|c|}{ Present method } \\
\hline & & & Clorsulon & Ivermectin \\
\hline & 99.9 & 99.3 & 98.5 & 98.6 \\
\hline & 98.9 & 97.7 & 97.7 & 97.6 \\
\hline Mobile phase ratio $(50: 40: 10: \mathrm{v} / \mathrm{v} / \mathrm{v})$ & 98.4 & 97.7 & 97.4 & 97.3 \\
\hline \multirow[t]{3}{*}{ Aceto: $\mathrm{MeOH}: \mathrm{PW}$} & 98.2 & 97.8 & 98.1 & 97.9 \\
\hline & 98.4 & 97.3 & 97.5 & 97.4 \\
\hline & 98.2 & 96.8 & 97.2 & 97.0 \\
\hline STDEV & 0.65 & 0.84 & 0.48 & 0.56 \\
\hline $\mathrm{RSD} \%$ & 0.66 & 0.86 & 0.49 & 0.57 \\
\hline
\end{tabular}

(Overall RSD) $* * *$ Acceptance Criteria: $\mathrm{RSD} \leq 2 \%$.

Table 18. Summary of Robustness Parameters.

\begin{tabular}{llll}
\hline Parameters & RT \pm SD & Theo. plates \pm SD & Tailing Factor \\
\hline Present Method & $1.72 \pm 0.1$ & $1520.49 \pm 1.2$ & 1.43 \\
$246 \mathrm{~nm}$ & $1.72 \pm 0.05$ & $1539.78 \pm 1.4$ & 1.54 \\
$0.8 \mathrm{ml} / \mathrm{min}$ & $2.14 \pm 0.12$ & $1701.04 \pm 7.2$ & 1.44 \\
Changed M. phase ratio & $1.72 \pm 0.2$ & $2191.6 \pm 2.9$ & 1.530 \\
\hline
\end{tabular}

Table 19. Summary of Robustness Parameters Ivermectin.

\begin{tabular}{llll}
\hline Parameters & RT \pm SD & Resolution \pm SD & Theo. plates \pm SD \\
\hline Present Method & $6.91 \pm 0.2$ & $20.55 \pm 0.3$ & $7106.94 \pm 0.1$ \\
$246 \mathrm{~nm}$ & $6.96 \pm 0.4$ & $20.26 \pm 3.09$ & $6742.26 \pm 6.05$ \\
$0.8 \mathrm{ml} /$ min & $9.02 \pm 0.2$ & $22.49 \pm 1.1$ & $8014.90 \pm 0.6$ \\
Changed M. phase ratio & $6.45 \pm 0.7$ & $20.25 \pm 0.8$ & $6528.74 \pm 1.1$ \\
\hline
\end{tabular}


Force degradation Study

Table 20. Summary result of the Force degradation.

\begin{tabular}{lll}
\hline \multirow{2}{*}{ Parameters } & \multicolumn{2}{c}{ Assay\% } \\
\cline { 2 - 3 } & CLO & IVM \\
\hline Present Method No Stress ( as STD ) & 97.50 & 97.48 \\
Thermal degradation & 97.71 & 96.58 \\
Acid degradation & 94.72 & 78.59 \\
Base degradation & 94.23 & 72.88 \\
Oxidation degradation & 97.57 & 91.70 \\
Photo degradation (UV) & 96.76 & 96.19 \\
\hline
\end{tabular}

Discussion

In this work an analytical HPLC method for simultaneous determination of Ivermectin plus injection (Ivermectin + Clorsulon) was developed and validated. The basic chromatographic conditions were designed to be simple and easy to use and reproduce and were selected after testing the different conditions that affect HPLC analysis, for example column, aqueous and organic components of the mobile phase, proportion of mobile phase components, detection wavelength, diluents and concentration of analyte.

To obtain better separation with good resolution these Chromatographic conditions were optimized using a stainless steel column (Thermo BDS C 18,150mm x 4.6mm 5.0m ), which was maintained at Ambient Temperature. The analytical wavelength was set at $245 \mathrm{~nm}$ and samples of 10 . $\mu \mathrm{l}$ were injected to HPLC system. The mobile phase consisting of a mixture of Acetonitrile: Methanol: Purified Water in the ratio $(60: 30: 10)$, at a flow rate of $1 \mathrm{ml} / \mathrm{min}$. The mobile phase was filtered through $0.45 \mathrm{~m} \mu$ filter and degassed for 10 minutes by sonication.

To determine linearity a calibration graph was obtained by plotting Ivermectin + Clorsulon injection concentration against peak area. The method was linear in the range of (10 - $40 \mu \mathrm{g} / \mathrm{ml})$ and $(100-400 \mu \mathrm{g} / \mathrm{ml})$ for Ivermectin and Clorsulon concentrations respectively with a correlation coefficient 0.9998 for Ivermectin and 0.9998 for Clorsulon for more detail refer to tables 3 to 6 and figures $3 \& 4$.

To determent the Specificity which is the ability of a method to discriminate between the analyte (s) of interest and other components that are present in the sample. The method shows no interference from placebo was observed at the retention time of the drugs peaks. (See Figure 5 and 6.

The accuracy of the method was assessed by determination of recovery for three concentrations covering the range of the method. The amount of Ivermectin and Clorsulon were recovered in the presence of placebo interference, were calculated. The mean recovery of Ivermectin and Clorsulon were $99.43 \%$ and $99.92 \%$ respectively which is satisfactory and result was shown in Table 7 and 8 .

Precision of the method was done; the $\%$ RSD for repeatability (Intra-day precision) were $0.34 \%$ and $0.59 \%$ for Ivermectin and Clorsulon respectively. The $\%$ RSD for intermediate precision were $0.65 \%$ and $1.0 \%$ for Clorsulon and Ivermectin respectively, Tables 11 to 14 explain the results of the inter-day precision test (intermediate precision). The method was found to be precise Since the RSD\% is less than $2.0 \%$

The robustness of the method was assessed by assaying test solutions under different analytical conditions deliberately changed from the original conditions such as wavelength, flow rate and mobile phase ratio. Assay and system suitability parameters of changed method conditions compared with the original method proves that the analytical method remained unaffected by slight but deliberate changes in the analytical conditions therefore the method is robust. See the results in tables 15, 16, 17, 18 and 19 .

A stability-indicating ability of the method is studied by a deliberate degradation through exposure of Ivermectin plus (Clorsulon $100+$ Ivermectin $10 \mathrm{mg}$ ) to acid hydrolysis, base hydrolysis, photo degradation (U V), heat and Oxidation. The acid and base hydrolysis are significantly affect the two drugs and the resulting degradants are very remarkable in the chromatograms while the other degrading substances show no or very slight influence on the two drugs for details refer to Table 20.

This furnished evidence that the method is suitable for its intended purpose.

\section{Conclusion}

The intensive approach described in this manuscript was used to develop and validate a liquid chromatographic analytical method that can be used for simultaneous determination of Ivermectin and Clorsulon in a pharmaceutical dosage form (injection). This HPLC -method for simultaneous estimation of the combined drug was successfully developed and validated for its intended purpose. The method clearly proves to be specific, linear, precise, accurate, robust and Stability-Indicating.

\section{References}

[1] Oltean E. G. and Nica A (2011), Development and Validation of a RP- HPLC Method for the. Quantitation Studies of Ivermectin in Solutions Dosage Forms, Veterinary Drugs, 5 (2), 68-70.

[2] Prieto J. G. and Merino G, 2003, Improved LC Method to Determine Ivermectin in Plasma, J. Pharma. Bio. Ana.; 31, 639-645.

[3] International Bulletin of Drug Research., 4 (6): 140-147, 2014 [147].

[4] Oka A H. and Ikai Y, Separation of Ivermectin Components by High-Speed Counter-Current Chromatography. chroma. A, 1996; 723, 61-68.

[5] Reuvers Th. and Dlaz R, (1993), Rapid Screening Method for Ivermectin Residue Detection in Cattle Muscle and Liver by Liquid Chromatography with UV Detection, Ana. Chemica. Acta, 275, 353-358.

[6] Harod S. S. and Manocha N, (2012) Development and validation of analytical method for fluconazole and ivermectin in tablet formulation by using RP-HPLC. IRJ. of pharmacy; $3,257-261$. 
[7] The United States Pharmacopoeia, 24th revision, pp. 17-39, U. S. Pharmacopeial Convention, Rockville, MD, 2007.

[8] British Pharmacopoeia CD 2013, version 17, The Stationery O_ce Ltd., Norwich, 2013.

[9] European Pharmacopoeia 1997, third edition, pp. 748-749, Convention on the Elaboration of a European.

[10] Ivermectin, Written by P. Junquera Last Updated on December 20, 2014, available at PARASITIPEDIA.net.
[11] European public MRL assessment report (EPMAR) for Clorsulon (extrapolation to milk) EMA/CVMP/813332/2011. Website www.ema.europa.eu.

[12] ICH guideline Q2 (R1). Validation of analytical procedures: textsand methodology. Geneva: 1996.

[13] ICH, Q2B (1993). Validation of Analytical Procedure: Methodology, International Conference on Harmonization, Geneva, March 1996. Reviewer Guidance, Validation of Chromatographic Methods, Center for Drug Evaluation and Research, Food and Drug Administration, USA, 1994. 